\title{
Is improvement of fatigue in rheumatoid arthritis a proper effect of biologics?
}

\author{
MAHMOUD INES ${ }^{1,3}$, BEN TEKAYA AICHA ${ }^{1,3}$, ROUACHED LEILA $^{1,3}$, MRABET ALI $^{2,3}$, \\ GUERMAN THOURAYA ${ }^{1}$, TEKAYA RAWDHA ${ }^{1,3}$, SAIDANE OLFA $^{1,3}$, \\ ABDELMOULA LEILA ${ }^{1,3}$ \\ ${ }^{1}$ Charles Nicolle Hospital, Department of Rheumatology, Tunis, Tunisia \\ ${ }^{2}$ Military Hospital, Department of Epidemiology, Tunis, Tunisia \\ ${ }^{3}$ Faculty of Medicine of Tunis, University Tunis el Manar, Tunis, Tunisia
}

\begin{abstract}
Background. The objective of our present study is to assess the relation between persistent fatigue and rheumatoid arthritis (RA) disease activity and its functional impact and to determine if the positive effect of biologics on fatigue is due to good disease response or to a different pathway.

Methods. A study cohort of patients with established RA was conducted. We included patients who had been prescried a biologic after at least failure of one conventional synthetic Disease Modifying Anti-Rheumatic Drug synthetic (csDMARDs). At baseline, patients had a moderately to highly active disease. Demographic characteristics, disease activity and functional impact were assessed by disease activity score (DAS28CRP) and health assessment questionnaire (HAQ) scores. Fatigue was evaluated by the Functional Assessment of Chronic Illness Therapy-Fatigue scale questionnaire (FACIT-F). Patients were examined before initiating biotherapy, then after three months and six months.

Results. Thirty women with RA, with a mean age of 52.5 years, were included. At baseline, 57\% received anti-TNF $\alpha$ : Etanercept $(n=9)$, Adalimumab $(n=6)$, Infliximab $(n=2)$ and $43 \%$ received Rituximab. Good Eular response was obtained in $80 \%$ of patients at the third month and $97 \%$ of patients at the sixth month. In the analytic study, a significant amelioration after 3 months of biotherapy was found in both disease response (DAS28CRP) and fatigue (FACIT-F), respectively $(p=0.01, p<0.001$ and $p<0.001)$. The disease activity decreased significantly also after sixth month $(p=0.01, p<0.001$ and $p=0.012)$. In the linear multivariate analysis, the regression of visual analogic pain (VAS pain) was the only predictors of the improvement of fatigue.

Conclusion. Biologics contribute to improve fatigue in patients with established RA and this effect seems to be independent from the clinical efficacy of this treatment.
\end{abstract}

Key words: fatigue, rheumatoid arthritis, biotherapy.

\section{INTRODUCTION}

Fatigue is common in patients with Rheumatoid Arthritis (RA), which is frequently considered as an extra-articular symptom. Indeed, nine out of ten patients report being tired and this fatigue exists at all stages of the disease, it typically increases during flares [1]. It has many causes and multiple mechanisms.

Fatigue is often reported as a major factor of deterioration in the quality of life (QOL) in chronic patients [2] and in particular in RA [3, 4]. Fatigue has no impact on the physical component nor it in psychological and social domains of QOL [5].

Evidence of efficacy of biotherapy has been brought from a cross-sectional study, especially for early RA [6]. However, less improvement in the QOL should be expected in patients with established RA than in those with early RA [7], and it is probably the same for tiredness.

Yet, until recent years, health professionals have paid little attention to fatigue, its multidimensional nature and its impact on QOL of patients with RA $[8,9]$. In fact about $90 \%$ of rheumatologists report that they do not assess fatigue throughout the follow-up of patients and only $4 \%$ of physicians evaluate fatigue at least $75 \%$ of the time [10]. Unlike pain or functional impairment, fatigue is rarely seen as a therapeutic target in itself or as a key criterion for evaluation of drugs such as biological therapy in clinical trials [11]. Moreover, its association with clinico-biologic and functional improvement under biologics has not been fully approached in the literature.

The objective of this study was to determine if the improvement of fatigue under biologics in 
patients with RA is related to inflammation and disease activity outcomes or it is a proper effect of biotherapy.

\section{MATERIALS AND METHODS}

A cohort study was conducted in the Department of Rheumatology of Charles Nicolle Hospital of Tunis (Tunisia) between January 2013 and January 2014. Included patients fulfilled the 2010 ACR/EULAR RA classification criteria or the 1987 ACR classification criteria and were with an established RA [12]. At the time of inclusion, patients were hospitalized for initiating a biologic after at least the failure of one csDMARDs or a switch after rituximab therapy. For all patients, disease activity at baseline was moderate to high, according to EULAR criteria [13] and had never received or were no longer in biotherapy for at least a year. Conventional synthetic Disease Modifying Anti-Rheumatic Drug synthetic (csDMARDs) was maintained in the same dose in association with biotherapy.

The study was approved by the Hospital local Ethics Committee, and informed consent was obtained from all participants.

Exclusion criteria were: any disease or condition that usually cause fatigue like known psychiatric diseases (depression, anxiety trouble), malignancy, anemia, diabetes, hypothyroidism, fibromyalgia, serious infections or systemic diseases, and other chronic diseases; patients who had hearing or comprehensive troubles; patients who did not receive at least three months of anti-tumor necrosis factor $\alpha$ (anti-TNF $\alpha$ ) or who have not received anti-CD20 treatment on Day 15 (adherence default or occurrence of adverse effects requiring discontinuation of treatment)

Demographic characteristics such as age and employment, sport activity, disease duration and age of disease onset were documented for each patient. Pain visual analogic scale (Pain VAS) and global patient assessment (PGA) were evaluated. Tender Joints count (TJC) and Swollen Joints Count (SJC) were assessed. The disease activity was evaluated by the Disease Activity Score CRP and ESR (DAS28 CRP and ESR), and the function by the Health assessment Questionnaire (HAQ).

All patients have had a complete physical examination, routine laboratory investigations including erythrocyte sedimentation rate (ESR), $\mathrm{C}$ reactive protein (CRP), Rheumatoid factor (RF), anti peptid citrullinated (ACPA) and radiological assessment with Modified Sharp scoring.

They also completed the self-administered questionnaires corresponding to the specific indices of the disease and to the fatigue evaluation by the Functional Assessment of Chronic Illness TherapyFatigue scale (FACIT-F) questionnaire. This selfadministered questionnaire comprising 13 questions was validated and used in a Tunisian dialect [14]. It is a sub-score of FACIT score which assesses specific quality of life concerns related to fatigue in cancer patients or other chronic diseases and includes physical, social, emotional and functional items. Each response is scored from 0 to 4 . The score ranges from 0 to 52 . Fatigue is considered low if the score is $\geq 40$, moderate between 20 and 40 , and severe if $<20$.

Patients were examined before initiating biological therapy (M0), three months (M3) and six months (M6) of starting treatment. At each visit we evaluated RA parameters including number of swelling and painful joints, VAS pain, DAS28ESR, DAS28CRP, ESR, CRP, HAQ and FACIT-F score.

\section{Statistical analysis}

Data were analyzed using SPSS software package version 11.5. Data were reported as means with standard deviations (SD), or as medians with interquartile ranges (IQR), if appropriate. The correlation between two quantitative variables was performed using the Pearson test and between two qualitative variables using the chi2 test. The Student's test was used to study the association between a qualitative and a quantitative variable. In case of small numbers, the Mann and Whitney test was used. The significance level was set at 0.05 .

Univariate and linear regression model was used to determine factors independently associated with fatigue. Significant factors $(p<0.05)$ were included. Results were presented as odds ratios (OR) with 95\% confidence interval (CI).

\section{RESULTS}

Thirty women with RA were included in the study. Demographic characteristics, disease activity parameters, and treatments of RA patients at baseline are shown in Table 1. 
At baseline, $57 \%$ received anti-TNF $\alpha$ : Etanercept $(n=9)$, Adalimumab $(n=6)$, Infliximab $(n=2)$ and $43 \%$ received Rituximab. Good Eular response was obtained in $80 \%$ of patients at the third month and $97 \%$ of patients at the sixth month.

Evolution of clinico-biological parameters and FACIT-F score at baseline, after third and sixth months are shown in Table 2.
At baseline, a positive correlation was found between FACIT-F T0 and disease duration $(\mathrm{r}=0.296$, $p=0.003)$, RF positivity $(r=0.468, p=0.008)$ and ACPA $(r=0.362, p=0.05)$ and negative correlation with age $(r=-0.308, p=0.002)$. In the linear regression analysis, an association between fatigue and DASCRP $(p=0.04)$ and DAS ESR $(p=0.02)$ was found. (Table 3 )

\section{Table 1}

Demographic characteristics, disease activity parameters, and treatments of RA patients at baseline

\section{PARAMETERS}

VALUE

Age: mean \pm SD (min-max) (years)

Employment

Unemployed, \%

Incapacity due to RA, \%

Regular sport activity, \%

Disease characteristics

Disease duration: mean \pm (min-max) (years)

Age of onset: mean $\pm \mathrm{SD}$ (min-max) (years)

$\mathrm{TJC}$ mean $\pm \mathrm{SD}$ (min-max)

$\mathrm{TSC}$ mean $\pm \mathrm{SD}$ (min-max)

GPA mean (min-max)

Pain VAS mean (min-max)

DAS28 ESR mean \pm SD (min-max)

DAS28 CRP mean \pm SD (min-max)

$\mathrm{CRP}(\mathrm{mg} / \mathrm{l})$ mean $\pm \mathrm{SD}$ (min-max)

ESR $(\mathrm{mm})$ mean $\pm \mathrm{SD}(\min -\max )$

Positive RF, \%

Positive ACPA, $\%$

Used Treatments

Methotrexate, \%

Sulfasalazine, $\%$

Leflunomide, $\%$

TNF blockers, $\%$

Rituximab, \%

Modified Sharp score mean \pm SD (min-max)

HAQ mean \pm SD (min-max)

FACIT-F score mean \pm SD (min-max)

Variables are presented as mean with determination of the extent. ESR Erythrocyte sedimentation rate, CRP C-reactive protein, Pain VAS: pain visual analogic scale, GPA: global patient assessment, HAQ: health assessment questionnaire, DAS28: disease activity score 28, TJC: tender joints count, SJC: swollen joint count, RF: rheumatoid factor, ACPA: anti-citrulinated protein antibody, FACIT-F: Functional Assessment of Chronic Illness Therapy-Fatigue scale

\section{Supplementary Table 1}

Correlation between the variation of FACIT-F and clinical parameters

\begin{tabular}{|c|c|c|c|c|}
\hline \multirow{10}{*}{$\triangle F A C I T-F$} & & Variable & $\mathbf{R}$ & $\mathbf{p}$ \\
\hline & \multirow{3}{*}{ V0-V3 } & $\triangle \mathrm{NAD}$ & -0.224 & 0.233 \\
\hline & & $\triangle \mathrm{NAG}$ & -0.211 & 0.262 \\
\hline & & $\triangle \mathrm{EVA}$ douleur & -0.379 & 0.004 \\
\hline & \multirow{3}{*}{ V3-V6 } & $\Delta \mathrm{NAD}$ & -0.477 & 0.008 \\
\hline & & $\triangle \mathrm{NAG}$ & -0.290 & 0.12 \\
\hline & & $\triangle \mathrm{EVA}$ douleur & -0.654 & 0.000 \\
\hline & \multirow{3}{*}{ V0-V6 } & $\triangle \mathrm{NAD}$ & -0.353 & 0.056 \\
\hline & & $\triangle \mathrm{NAG}$ & -0.123 & 0.517 \\
\hline & & $\triangle \mathrm{EVA}$ douleur & -0.725 & 0.000 \\
\hline
\end{tabular}

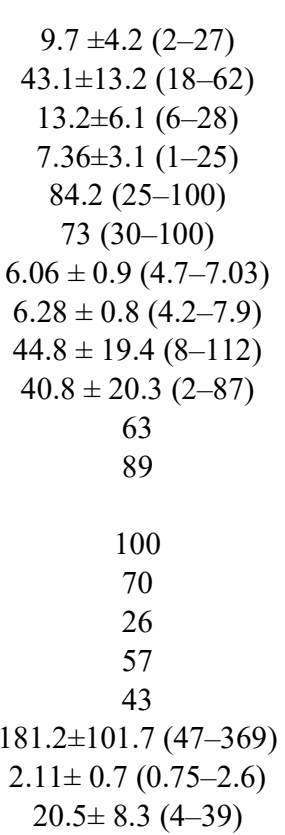


Table 2

Evolution of clinico-biological parameters and FACIT-F over time

\begin{tabular}{lccccc} 
& BASELINE & M3 & M6 & $\begin{array}{c}\text { P-VALUE } \\
\text { (M0-M3) }\end{array}$ & $\begin{array}{c}\text { P-VALUE } \\
\text { (M3-M6) }\end{array}$ \\
\hline TJC & 13.2 & 5.6 & 4.53 & $\mathbf{0 . 0 3}$ & $<\mathbf{0 . 0 0 1}$ \\
SJC & 7.36 & 2.6 & 1 & $\mathbf{0 . 0 4}$ & 0.09 \\
Pain VAS & 72.96 & 52 & 39.6 & $<\mathbf{0 . 0 0 1}$ & $\mathbf{0 . 0 5}$ \\
DAS28 ESR & 6.06 & 4.57 & 3.91 & $\mathbf{0 . 0 1}$ & 0.23 \\
DAS28 CRP & 6.28 & 3.81 & 3.43 & $\mathbf{0 . 0 1}$ & 0.01 \\
ESR (mm) & 40.8 & 35.14 & 33.84 & $\mathbf{0 . 0 2}$ & 0.69 \\
CRP(mg/l) & 44.86 & 24.23 & 10.23 & 0.9 & $\mathbf{0 . 0 2}$ \\
HAQ & 2.11 & 1.63 & 1.23 & $<\mathbf{0 . 0 0 1}$ & $<\mathbf{0 . 0 0 1}$ \\
FACIT-F & 20.5 & 29.06 & 35.06 & $<\mathbf{0 . 0 0 1}$ & $\mathbf{0 . 0 1 2}$
\end{tabular}

FACIT-F: Functional Assessment of Chronic Illness Therapy-Fatigue scale, ESR Erythrocyte sedimentation rate, CRP C-reactive protein, Pain VAS: pain visual analogic scale, GPA: global patient assessment, HAQ: health assessment questionnaire, DAS28: disease activity score 28, TJC: tender joints count, SJC: swollen joint count, RF: rheumatoid factor, ACPA: anti-citrulinated protein antibody, M3: third month, M6: sixth month.

Supplementary Table 2

Correlation between the variations of FACIT-F and biologic parameters

\begin{tabular}{lllll}
\hline & & Variable & r & P \\
\cline { 2 - 5 }$\Delta$ FACIT-F & \multirow{2}{*}{ V0-V3 } & $\Delta$ VS & 0.565 & 0.07 \\
& & $\Delta$ CRP & 0.093 & 0.66 \\
& V3-V6 & $\Delta$ VS & 0.548 & 0.053 \\
& $\Delta$ CRP & 0.203 & 0.282 \\
& V0-V6 & $\Delta$ VS & 0.424 & 0.09 \\
& & $\Delta$ CRP & 0.338 & 0.98 \\
\hline
\end{tabular}

Table 3

Parameters associated with fatigue in linear regression

\begin{tabular}{lll}
\hline & \multicolumn{1}{c}{ Variable } & p \\
\hline & Age & 0.395 \\
& Evolution time & 0.820 \\
& Seropositivity & 0.929 \\
\multirow{2}{*}{ FACIT-F TO } & SHARP & 0.721 \\
& CRP & 0.331 \\
& DAS28VS & $\mathbf{0 . 0 4 0}$ \\
& DAS28CRP & $\mathbf{0 . 0 2 6}$ \\
& EVA pain & 0.877 \\
\hline
\end{tabular}

Supplementary Table 3

Correlation $\triangle \mathrm{FACIT}-\mathrm{F}$ and $\triangle \mathrm{DAS} 28$

\begin{tabular}{|c|c|c|c|c|}
\hline \multirow{7}{*}{$\Delta$ FACIT-F } & & Variable & $\mathbf{r}$ & $\mathbf{P}$ \\
\hline & \multirow{2}{*}{$\mathrm{V} 0-\mathrm{V} 3$} & $\triangle \mathrm{DAS} 28 \mathrm{VS}$ & 0.042 & 0.907 \\
\hline & & $\triangle \mathrm{DAS} 28 \mathrm{CRP}$ & 0.470 & 0.09 \\
\hline & \multirow{2}{*}{ V3-V6 } & $\triangle \mathrm{DAS} 28 \mathrm{VS}$ & 0.616 & 0.250 \\
\hline & & $\triangle \mathrm{DAS} 28 \mathrm{CRP}$ & -0.595 & 0.001 \\
\hline & \multirow{2}{*}{ V0-V6 } & $\triangle \mathrm{DAS} 28 \mathrm{VS}$ & 0.158 & 0.519 \\
\hline & & $\triangle \mathrm{DAS} 28 \mathrm{CRP}$ & -0.586 & 0.000 \\
\hline
\end{tabular}

Univariate regression analysis showed that FACIT-F was negatively correlated with TJC, SJC and pain scale at baseline, M3 and M6. FACIT-F was also negatively correlated with DAS28ESR and CRP only in the sixth month.
There is an association between variation of FACIT-F score and variation of Pain VAS between baseline-M3 and M3-M6. Negative correlations were also found with the variation of TJC between M0-M3 and with variation of DAS28ESR between M3 and M6. 
We analyzed the correlation between baseline clinico-biologic and radiologic parameters with the improvement of tiredness (delta FACIT-F). There were no significantly parameters associated with fatigue improvement between M0 and M6 (Table 4).
Additional in another linear regression analysis, we found a significant association between variation of the FACIT-F between M0 and M6 and the variation of pain VAS and ESR only between M0-M3 (Table 5).

\section{Table 4}

Evaluation of the correlation of baseline parameters with FACIT-F variation

\begin{tabular}{l|lcc} 
& Variables & R & p-value \\
\hline \multirow{3}{*}{$\Delta$ FACIT-F T0-T6 } & TJC & -0.1 & 0.57 \\
& SJC & -0.05 & 0.79 \\
& ESR & 0.12 & 0.61 \\
& CRP & -0.3 & 0.13 \\
& DAS28ESR & -0.22 & 0.34 \\
& DAS28CRP & -0.29 & 0.11 \\
& Pain scale & 0.012 & 0.95 \\
& Sharp & -0.14 & 0.44 \\
& Disease duration & -0.28 & 0.13 \\
& Age & -0.23 & 0.21
\end{tabular}

FACIT-F: Functional Assessment of Chronic Illness Therapy-Fatigue scale, ESR Erythrocyte sedimentation rate, CRP C-reactive protein, Pain VAS: pain visual analogic scale, GPA: global patient assessment, DAS28: disease activity score 28, TJC: tender joints count, SJC: swollen joint count, RF: rheumatoid factor, ACPA: anti-citrulinated protein antibody, M3: third month, M6: sixth month.

Table 5

Linear regression models examined the impact of variation of clinicobiologic parameters on the improvement of tiredness

\begin{tabular}{|c|c|c|c|c|}
\hline & VARIABLE & M0-M3 & $\begin{array}{c}\text { P-VALUE } \\
\text { M3-M6 }\end{array}$ & M0-M6 \\
\hline \multirow{7}{*}{$\begin{array}{l}\Delta \text { FACIT-F } \\
\text { M0-M6 }\end{array}$} & $\Delta \mathrm{TJC}$ & 0.428 & 0.973 & 0.763 \\
\hline & $\Delta \mathrm{SJC}$ & 0.614 & 0.874 & 0.561 \\
\hline & $\Delta \mathrm{ESR}$ & $<0.001$ & 0.052 & 0.292 \\
\hline & $\Delta \mathrm{CRP}$ & 0.146 & 0.057 & 0.59 \\
\hline & $\triangle \mathrm{DAS} 28 \mathrm{ESR}$ & 0.219 & 0.807 & 0.116 \\
\hline & $\triangle \mathrm{DAS} 28 \mathrm{CRP}$ & 0.681 & 0.778 & 0.178 \\
\hline & $\Delta$ Pain VAS & 0.01 & 0.621 & $<0.001$ \\
\hline
\end{tabular}

FACIT-F: Functional Assessment of Chronic Illness Therapy-Fatigue scale, ESR Erythrocyte sedimentation rate, CRP C-reactive protein, Pain VAS: pain visual analogic scale, GPA: global patient assessment, , DAS28: disease activity score 28, TJC: tender joints count, SJC: swollen joint count, RF: rheumatoid factor, ACPA: anti-citrulinated protein antibody, M3: third month, M6: sixth month.

\section{DISCUSSION}

Results from this cohort study show a clear benefic effect of biologics, in established RA population, on clinico-biological parameters, including: disease activity, pain, TJC, SJC, ESR and CRP and on fatigue (FACIT-F score).

FACIT-F score was chosen in our study for the measure of fatigue. This choice was suitable because it is a reliable, validated and sensitive to changes score and showed good internal consistency. The extent of a six month follow-up was also a main strength in our study.

To know the effect of biotherapy on fatigue, several studies were done with different results [15-21]. Yount S et al. [19] conducted three randomized controlled trials (ARMADA study, DEO 19 study and STAR study) totaling 1,526 patients. They found a significant decrease in fatigue in patients receiving Adalimumab compared to placebo after three months in the three arms of the study. The same result was found in APPEAL study [20], which is a randomized study with an Asian population. Its purpose was to compare the efficacy of Etanercept compared to methotrexate in established RA. Three hundred patients were included. After 16 weeks of treatment improved FACIT-F score was $28 \%$ in the group Etanercept versus $10.4 \%$ in the DMARDs group. However, in another study, Wolf F [21] concluded that the effect of anti-TNF $\alpha$ on fatigue is not more important than the other treatments against RA but this may be because they did not measure fatigue before the introduction of biotherapy. They also concluded that the potential improvement of fatigue scores under anti TNF is primarily the result of decreased pain, improved quality of life and 
psychological status of patients rather than a direct effect on the cytokines responsible for fatigue in RA.

In our work we have not directly compared patients on DMARDs and under Anti TNF. However, all our patients were under DMARDs in the inclusion day, and the role of biologics in improving fatigue was statistically significant showing a significant positive effect on fatigue in patients failing DMARDs.

A meta-analysis was performed and included 10 randomized controlled trials assessing the effect of biotherapies $(1,227$ patients were treated with an anti-TNF, 420 with rituximab, 258 with abatacept, 205 with tocilizumab) versus placebo (1,727 patients) on fatigue, in combination with DMARDs. The results point out the overall effect sizes of all biotherapies versus placebo on fatigue were small and similar between anti-TNF and non-anti-TNF agents [22].

Due to the different nature and origins of fatigue in early compared with established RA, different effect of biotherapy on fatigue could be expected. Most of the clinical trials focused on early RA and demonstrated the benefic effect of such therapy. A further problem with trials is that they include patients with flares in their arthritis, and this may overestimate the effects of interventions in clinical trials. Few concerns were, however, taken on regards to established RA.

One of the most interesting studies who focused on established RA is the study of Moreland et al. [23] which is a randomized controlled trial whose objective was to investigate the long term effect of Etanercept on fatigue in two groups of patients with early (304 participants) and established RA (131 participants: 70 patients under placebo and 63 patients under Etanercept). They concluded that this molecule caused a significant decrease of the level of fatigue compared to placebo even in the group with established RA. This decrease was maintained during the 44-month follow-up. In addition this improvement of the fatigue scores was associated with the reduction of pain in the two groups.

In a cross-sectional study, Pollard et al. [24] compared fatigue between two groups of patients; one was under DMARDs and the other group was put under anti TNF. After only three months of treatment, the decrease in fatigue score was seen more significantly in the anti TNF arms. This relatively rapid decline in mean VAS fatigue was correlated with the decrease in pain and disease activity assessed by DAS $28(\mathrm{r}=0.65, \mathrm{p}=0.001$; $\mathrm{r}=0.43, \mathrm{p}=0.019$; respectively). These authors also suggested that improvement of fatigue under anti TNF may be due to a direct central effect by interacting with sensory neurons. Efficacy of Rituximab on fatigue was also shown by Rigby W et al. [25], according to the authors the declining level of fatigue would not be correlated to the decrease in the activity of the disease but it is due to the improvement in pain and normalization of inflammatory cytokine levels related to RA.

Thereby, different results were found in the literature; in fact, some studies have concluded that the occurrence and intensity of fatigue were mainly related to the degree of disease activity and some others to the presence of an inflammatory syndrome.

Other studies suggest that fatigue is not related to the disease activity but would be especially associated with pain in functional status and especially with other symptoms such as sleep disorders, anxiety and depression [26-30]. Recently, Corominas et al. reported through a multicenter study that Tocilizumab, received failure or intolerance to DMARDs or TNF inhibitor, significantly improved fatigue in RA. Sleepiness, depression and DAS28 were the parameters identified as factors explaining fatigue variance with the use of Tocilizumab in RA patients [26]. This may be due to multifactorial, complex and not clearly understood fatigue which also explains the difficulty of treatment. However, a recent cochrane review identified 32 randomized controlled trials: 22 studies evaluated five anti-TNF and 12 studies focused on five non-anti-TNF biologic agents (abatacept, canakinumab, rituximab, tocilizumab and an anti-interferon gamma monoclonal antibody). Authors concluded that treatment with biologic interventions in patients with active RA can lead to a small to moderate improvement in fatigue which was similar for antiTNF and non-anti-TNF biologics. It was unclear whether the improvement results from a direct action of the biologics on fatigue or indirectly through reduction in inflammation, disease activity or some other mechanism [31].

Moreover, a new paper described monthly and seasonal variations in fatigue, in persons with RA of working age. This study showed that fluctuations in fatigue, general and physical fatigue being significantly greater during the winter [32].

In our study, VAS pain was the best independent predictors of the decrease in fatigue after 6 months of biotherapy.

The variation of ESR and CRP had an impact only during the first three months, and disease activity scores (DAS28CRP and ESR) were not associated to the improvement of fatigue score. So we can 
consider that disease activity has no significant effect on fatigue.

Nevertheless, our study has some shortcomings; in fact, it was a monocentric study and the small number of our patients did not allow statistically reliable results especially in subgroups with different biologics. However, this is one of the risks of real life studies. A study with a larger workforce may overcome these limitations. Moreover, we did not search for a steroid use with biotherapy and its impact on fatigue. Finally, we did not mention the extra articular manifestations that also may contribute on fatigue.

\section{CONCLUSIONS}

Our study demonstrated that biotherapy use has a positive impact on RA disease activity and tiredness. Also, VAS pain decrease was the only predictor of the improvement of fatigue. This effect seems to be independent from the efficacy of this treatment on disease activity.

Introducere. Obiectivul studiului a fost de a evalua relația dintre oboseala persistentă și activitatea bolii în artrita reumatoidă (AR) și impactul funcțional, precum și de a determina dacă efectul pozitiv al tratamentului cu biologice este datorat răspunsului bolii sau altor cauze.

Materiale şi metode. Au fost recrutați pacienți cu AR care aveau inițiată terapia cu biologice după cel puțin un eșec la terapia convențională cu csDMARDs. La momentul inițierii terapiei, pacienții aveau boală moderat activă. Scorul DAS28CRP şi HAQ au fost evaluate pentru a măsura impactul şi severitatea bolii. Oboseala a fost evaluată folosind scorul Functional Assessment of Chronic Illness TherapyFatigue scale questionnaire (FACIT-F). Pacienții au fost evaluați înaintea inițierii tratamentului, precum și la 3 și 6 luni după tratament.

Rezultate. Au fost urmărite 30 de femei cu AR având vârstă medie de 52,5 ani. $57 \%$ au primit anti-TNF : Etanercept $(n=9)$, Adalimumab $(n=6)$, Infliximab $(n=2)$ şi $43 \%$ au primit Rituximab. $80 \%$ dintre paciente au avut răspuns bun terapeutic la 3 luni de tratament și 97\% la 6 luni. După 3 luni s-a observat o ameliorare atât din punct de vedere al activității bolii, cât și din punct de vedere al oboselii. Activitatea bolii a scăzut și la 6 luni. În modelul de regresie multivariată scăderea durerii pe scala vizuală analogă a fost singurul predictor pentru îmbunătătirea oboselii.

Concluzii. Tratamentul cu biologice reduce oboseala la pacienții cu AR și acest efect pare să fie independent de eficiența clinică a tratamentului.

Correspondence to: Rouached Leila, M.D, Charles Nicolle Hospital, Department of Rheumatology, Tunis, Tunisia Telephone number: 0021621482262

Email address: leila_rouached@hotmail.com

\section{REFERENCES}

1. BARENDREGT PJ, VISSER MRM, SMETS EMA, TULEN JH, VAN DEN MEIRACKER AH, BOOMSMA F et al. Fatigue in primary Sjogren's syndrome. Ann Rheum. 1998; 57: 291-5.

2. SWAIM M. Fatigue in chronic disease. Clin Sci. 2000; 9: 1-8.

3. HUYSE BAR, PARKER JC, THORESON R, SMARR KL, JOHNSON JC, HOFFMAN R. Predictors of subjective fatigue among individuals with rheumatoid arthritis. Arthritis Rheum. 1998; 41:2230-7.

4. WOLFE F, HAWLEY DJ, WILSON K. The prevalence and meaning of fatigue in rheumatic disease. J Rheumatol. 1996; 23:1407-17.

5. SUURMEIJER TP, WALTZ M, MOUM T, GUILLEMIN F, VAN SONDEREN FLP, BRIANCON S et al. Quality of life profiles in the first years of rheumatoid arthritis: results from the EURIDISS longitudinal study. Arthritis Rheum. 2001; 45:111-21.

6. CAMPBELL RC, BATLEY M, HAMMOND A, IBRAHIM F, KINGSLEY G, SCOTT DL. The impact of disease activity, pain, disability and treatments on fatigue in established rheumatoid arthritis. Clin Rheumatol. 2012; 31:717-22.

7. KINGSLEY G, SCOTT I C AND SCOTT DL. Quality of life and the outcome of established rheumatoid arthritis. Best Practice \& Research Clinical Rheumatology. 2011; 25: 585-606. 
8. HEWLETT S1, COCKSHOTT Z, BYRON M, KITCHEN K, TIPLER S, POPE D, et al. Patient's perception of fatigue in rheumatoid arthritis: overwhelming, uncontrollable, ignored. Arthritis Rheum. 2005; 53:697-702.

9. HIDER SL1, TANVEER W, BROWNFIELD A, MATTEY DL, PACKHAM JC. Depression in RA patients treated with antiTNF is common and under recognized in the rheumatology clinic. Rheumatology. 2009; 48:1152-4.

10. FLOWERS N, WOLFE F. What do rheumatologists do in their practices? Arthritis Rheum. 1998; 41:337.

11. FELSON DT, ANDERSON JJ, BOERS M, BOMBARDIER C, CHERNOFF M, FRIED B et al. The American College of Rheumatology preliminary core set of disease activity measures for rheumatoid arthritis clinical trials. The Committee on outcome measures in rheumatoid arthritis clinical trials. Arthritis Rheum. 1993; 36:729-40.

12. CONAGHAN PG, GREEN MJ AND EMERY P. Established rheumatoid arthritis. Baillieres Best Pract Res Clin Rheumatol. 1999; 13:561-575

13. VAN GESTEL, A. M., M. L. PREVOO, et al. Development and validation of the European League Against Rheumatism response criteria for rheumatoid arthritis. Comparison with the preliminary American College of Rheumatology and the World Health Organization/International League Against Rheumatism Criteria. Arthritis Rheum. 1996; 39(1): 34-40.

14. CELLA D, YOUNT S, SORENSEN M, CHARTASH E, SENGUPTA N, GROBER J. Validation of the Functional Assessment of Chronic Illness Therapy Fatigue Scale relative to other instrumentation in patients with rheumatoid arthritis. J Rheumatol. 2005; 32:811-9.

15. DETERT J, DZIURLA R, HOFF P, GABER T, KLAUS P, BASTIAN H, et al. Effects of treatment with etanercept versus methotrexate on sleep quality, fatigue and selected immune parameters in patients with active rheumatoid arthritis. Clin Exp Rheumatol 2016; 34:848-56.

16. GENTY M, COMBE B, KOSTINE M, ARDOUIN E, MOREL J, LUKAS C. Improvement of fatigue in patients with rheumatoid arthritis treated with biologics: relationship with sleep disorders, depression and clinical efficacy. A prospective, multicentre study. Clin Exp Rheumatol 2017; 35:85-92.

17. GOSSEC L, STEINBERG G, ROUANET S, COMBE B. Fatigue in rheumatoid arthritis: quantitative findings on the efficacy of tocilizumab and on factors associated with fatigue. The French multicentre prospective PEPS Study. Clin Exp Rheumatol 2015; 33:664-70.

18. YOUNT S, SORENSEN MV, CELLA D, SENGUPTA N, GROBER J, CHARTASH EK. Adalimumab plus methotrexate or standard therapy is more effective than methotrexate or standard therapies alone in the treatment of fatigue in patients with active, inadequately treated rheumatoid arthritis. Clin Exp Rheumatol 2007; 25:838-46.

19. BAE SC, GUN SC, MOK CC, KHANDKER R, NAB HW, KOENIG AS, et al. Improved health outcomes with Etanercept versus usual DMARD therapy in an Asian population with established rheumatoid arthritis. BMC Musculoskeletal Disorders. 2013; 14:13.

20. WOLFE F, MICHAUD K, PINCUS T. Fatigue, rheumatoid arthritis, and anti-tumor necrosis factor therapy: an investigation in 24,831 patients. J Rheumatol. 2004; 31:2115-20.

21. ABU-SHAKRA M, ZISMAN D, BALBIR-GURMAN A, AMITAL H, LEVY Y, LANGEVITZ P, et al. Effect of Tocilizumab on Fatigue and Bone Mineral Density in Patients with Rheumatoid Arthritis. Isr Med Assoc J IMAJ 2018; 20:239-44.

22. CHAUFFIER K, SALLIOT C, BERENBAUM F, SELLAM J. Effect of biotherapies on fatigue in rheumatoid arthritis: a systematic review of the literature and meta-analysis. Rheumatology. 2012; 51(1):60-8.

23. MORELAND LW, GENOVESE MC, SATO R, SINGH A. Effect of etanercept on fatigue in patients with recent or established rheumatoid arthritis. Arthritis Rheum. 2006; 55:287-93.

24. POLLARD LC, CHOY EH, GONZALEZ J, KHOSHABA B, SCOTT DL. Fatigue in rheumatoid arthritis reflects pain, not disease activity. Rheumatology (Oxford). 2006; 45:885-9.

25. RIGBY W1, FERRACCIOLI G, GREENWALD M, ZAZUETA-MONTIEL B, FLEISCHMANN R, WASSENBERG S, et al. Effect of Rituximab on Physical Function and Quality of Life in Patients With Rheumatoid Arthritis Previously Untreated With Methotrexate. Arthritis Care \& Research. 2011; 5:711-20.

26. COROMINAS H, ALEGRE C, NARVAEZ J, FERNANDEZ-CID CM, TORRENTE-SEGARRA V, GOMEZ MR, et al. Correlation of fatigue with other disease related and psychosocial factors in patients with rheumatoid arthritis treated with tocilizumab: ACT-AXIS study. Medicine (Baltimore) 2019; 98:e15947.

27. MINNOCK P, VEALE DJ, BRESNIHAN B, FITZGERALD O, MCKEE G. Factors that influence fatigue status in patients with severe rheumatoid arthritis (RA) and good disease outcome following 6 months of TNF inhibitor therapy: a comparative analysis. Clin Rheumatol 2015; 34:1857-65.

28. EGSMOSE EL, MADSEN OR. Fatigue in Patients with Rheumatoid Arthritis Selected for Biological Treatment in the Daily Clinic: Associations with Classical Measures of Disease Activity. Ann Rheum Dis. 2014; 73:412-413.

29. LISITSYNA TA, SERAVINA O, KOVALEVSKAYA O, VELTISHCHEV D, ZELTYN A, NOVIKOVA D et al. Fatigue in rheumatoid arthritis patients: The impact of disease activity, pain, disability and depressive disorders. Ann Rheum Dis. 2013; $71: 179$.

30. DRUCE KL, JONES GT, MACFARLANE GJ, BASU N. Determining Pathways to Improvements in Fatigue in Rheumatoid Arthritis: Results From the British Society for Rheumatology Biologics Register for Rheumatoid Arthritis. Arthritis Rheumatol. 2015; 67(9):2303-10.

31. ALMEIDA C, CHOY EHS, HEWLETT S, KIRWAN JR, CRAMP F, CHALDER T, et al. Biologic interventions for fatigue in rheumatoid arthritis. Cochrane Database Syst Rev 2016.

32. FELDTHUSEN C, GRIMBY-EKMAN A, FORSBLAD-D'ELIA H, JACOBSSON L, MANNERKORPI K. Seasonal variations in fatigue in persons with rheumatoid arthritis: a longitudinal study. BMC MusculoskeletDisord. 2016; 17:59.

Received $1^{\text {st }}$ August 2020 